\title{
Erratum to: Modeling of air pollutant concentrations in an industrial region of Turkey
}

\author{
Gizem Tuna Tuygun ${ }^{1} \cdot$ Hicran Altuğ ${ }^{2}$ Tolga Elbir ${ }^{1}$ Eftade E. Gaga ${ }^{2}$
}

Published online: 21 March 2017

(C) Springer-Verlag Berlin Heidelberg 2017

Erratum to: Environ Sci Pollut Res

DOI 10.1007/s11356-017-8492-9

The sentence in the acknowledgement was revised as:

"This study was supported by The Scientific and Technological Research Council of Turkey (TUBITAK) (project no: 112Y305) and Anadolu University Research Fund (project no: 1306F272)".

The online version of the original article can be found at http://dx.doi. org/10.1007/s11356-017-8492-9

Tolga Elbir

tolga.elbir@deu.edu.tr

1 Department of Environmental Engineering, Dokuz Eylül University, İzmir, Turkey

2 Department of Environmental Engineering, Anadolu University, Eskișehir, Turkey 